\title{
Blood-Nerve Barrier (BNB) Pathology in Diabetic Peripheral Neuropathy and In Vitro Human BNB Model
}

\author{
Yukio Takeshita, Ryota Sato and Takashi Kanda *
}

Citation: Takeshita, Y.; Sato, R.; Kanda, T. Blood-Nerve Barrier (BNB) Pathology in Diabetic Peripheral Neuropathy and In Vitro Human BNB Model. Int. J. Mol. Sci. 2021, 22, 62.

https://dx.doi.org/10.3390/ ijms22010062

Received: 20 November 2020 Accepted: 18 December 2020 Published: 23 December 2020

Publisher's Note: MDPI stays neutral with regard to jurisdictional claims in published maps and institutional affiliations.

Copyright: () 2020 by the authors. Licensee MDPI, Basel, Switzerland. This article is an open access article distributed under the terms and conditions of the Creative Commons Attribution (CC BY) license (https: / / creativecommons.org/ licenses/by/4.0/).
Department of Neurology and Clinical Neuroscience, Graduate School of Medicine, Yamaguchi University, Yamaguchi 753-8511, Japan; takeshy@yamaguchi-u.ac.jp (Y.T.); ryota214@yamaguchi-u.ac.jp (R.S.)

* Correspondence: tkanda@yamaguchi-u.ac.jp

\begin{abstract}
In diabetic peripheral neuropathy (DPN), metabolic disorder by hyperglycemia progresses in peripheral nerves. In addition to the direct damage to peripheral neural axons, the homeostatic mechanism of peripheral nerves is disrupted by dysfunction of the blood-nerve barrier (BNB) and Schwann cells. The disruption of the BNB, which is a crucial factor in DPN development and exacerbation, causes axonal degeneration via various pathways. Although many reports revealed that hyperglycemia and other important factors, such as dyslipidemia-induced dysfunction of Schwann cells, contributed to DPN, the molecular mechanisms underlying BNB disruption have not been sufficiently elucidated, mainly because of the lack of in vitro studies owing to difficulties in establishing human cell lines from vascular endothelial cells and pericytes that form the BNB. We have developed, for the first time, temperature-sensitive immortalized cell lines of vascular endothelial cells and pericytes originating from the BNB of human sciatic nerves, and we have elucidated the disruption to the BNB mainly in response to advanced glycation end products in DPN. Recently, we succeeded in developing an in vitro BNB model to reflect the anatomical characteristics of the BNB using cell sheet engineering, and we established immortalized cell lines originating from the human BNB. In this article, we review the pathologic evidence of the pathology of DPN in terms of BNB disruption, and we introduce the current in vitro BNB models.
\end{abstract}

Keywords: blood-nerve barrier; pericyte; Schwann cells; advanced glycation end products

\section{Introduction}

Diabetes mellitus, especially type 2 diabetes mellitus, affects approximately 463 million people worldwide and is expected to affect more than 700 million people by 2045 [1] Diabetic peripheral neuropathy (DPN) is one of the most common complications of diabetes mellitus and occurs in $30 \%-50 \%$ of patients with type 2 diabetes mellitus [2]. DPN is considered to occur in $100 \%$ of patients with type 1 diabetes mellitus within a disease duration of 15 years and in 30\% of patients with type 2 diabetes mellitus within a disease duration of 25 years [3]. As overcoming DPN is an important global challenge, studies have been conducted on the pathology of DPN and have proposed various pathological hypotheses.

In peripheral nerve tissues, where glucose is taken up by non-insulin-dependent glucose transporters, most of the glucose is transported from blood vessels to peripheral nerve tissues, according to the concentration gradient. Hyperglycemia directly contributes to the elevation of intracellular glucose concentrations. In a hyperglycemic state, the polyol metabolic pathway is enhanced via increased activity of aldose reductase in peripheral nerve tissues [4]. Edema, degeneration, and ischemia of nerves are considered to occur via various mechanisms, such as osmotic stress, abnormal protein kinase $C$ activity, increased oxidative stress, accumulation of advanced glycation end products (AGEs) due to impaired glucose metabolism, and decreased production of nitric oxide [5]. Notably, disruption of the blood-nerve barrier (BNB), a strict barrier system that stabilizes the internal environment of peripheral nerves, has been increasingly reported to be deeply involved in the onset and 
exacerbation of DPN with in vitro BNB models. Here, we present recent findings on the pathology of DPN in terms of BNB disruption and recommend our current in vitro BNB models.

\section{Anatomy of the BNB and Peripheral Nerves}

Peripheral nerve tissues mainly compose the BNB, Schwann cells, and nerve axons. The BNB is mainly localized in the microvessels of peripheral nerves within the peripheral neural parenchyma (endoneurium) and consists of vascular endothelial cells bound by tight junction proteins, pericytes attached to the outer side of the vascular endothelial cells, and basal laminae covering these two types of cells. Like the blood-brain barrier (BBB) in the central nervous system, the BNB acts as a wall preventing the influx of harmful substances circulating in the blood into peripheral nerves [6]. The BBB is mainly composed of brain microvascular endothelial cells, pericytes, astrocytes, and the two distinct basement membranes. The BNB has a similar structure to the BBB, with the exception of lacking astrocytes (Figure 1A). It had previously been thought that the BNB was leaky compared to the $\mathrm{BBB}$, as a result of the lack of astrocytes, but several reports showed that the BNB has a barrier function as robust as that of the BBB $[7,8]$ and acts as an interface to maintain the microenvironment in peripheral nerves by expressing transporters for the transportation of nutrients, such as glucose and amino acids, as well as for the excretion of waste products [6,9]. The basement membrane in the BBB and BNB consists of a mixture of extracellular matrix proteins including collagen IV and laminin [10]. Laminin is a trimeric molecule comprising $\alpha-, \beta-$, and $\gamma$-subunits and shows specific expression in the central and peripheral nervous systems [10]. We showed that laminin $\alpha 4$ was hardly expressed in the BNB compared with the BBB (Figure 1B), whereas $\alpha 5, \beta 1, \beta 2$, and $\gamma 1$ were widely expressed in the BBB and BNB [11]. In experimental autoimmune encephalomyelitis, a relevant preclinical model of multiple sclerosis laminin $\alpha 4$ facilitates the transmigration of $\mathrm{T}$ lymphocytes across the BBB because integrin $\alpha 6 \beta 1$, a major counterpart receptor of laminin $\alpha 4$, is strongly expressed on all $\mathrm{T}$ lymphocytes [12]. These results showed that $\mathrm{T}$ lymphocytes, with integrin $\alpha 6 \beta 1$, migrated across the BNB through other factors (except for laminin $\alpha 4$ in peripheral autoimmune neuropathies), suggesting the BNB has its own barrier system because of a lack of laminin $\alpha 4$ in the BNB. On the other hand, laminin $\alpha 5$ plays a key role in the maintenance and repair of BBB after hypoxic injury and inflammation [13]. Therefore, we hypothesized that BNB-specific laminin expression without laminin $\alpha 4$ might promote almost the same properties as a barrier system as those with the BBB.

In contrast, Schwann cells surround the axons of neurons to form a myelin sheath, a structure responsible for saltatory conduction. Together with pericytes, Schwann cells are involved in providing nutrients to neurons and play a role in maintaining the microenvironment [14]. 

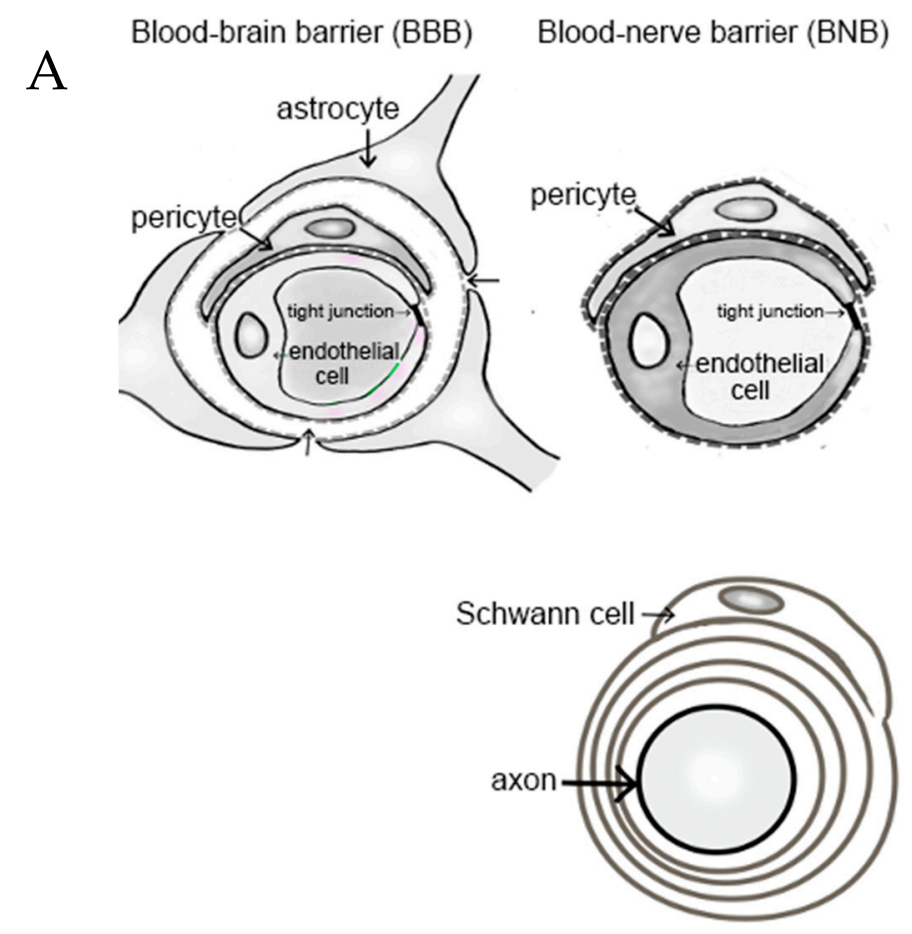

B
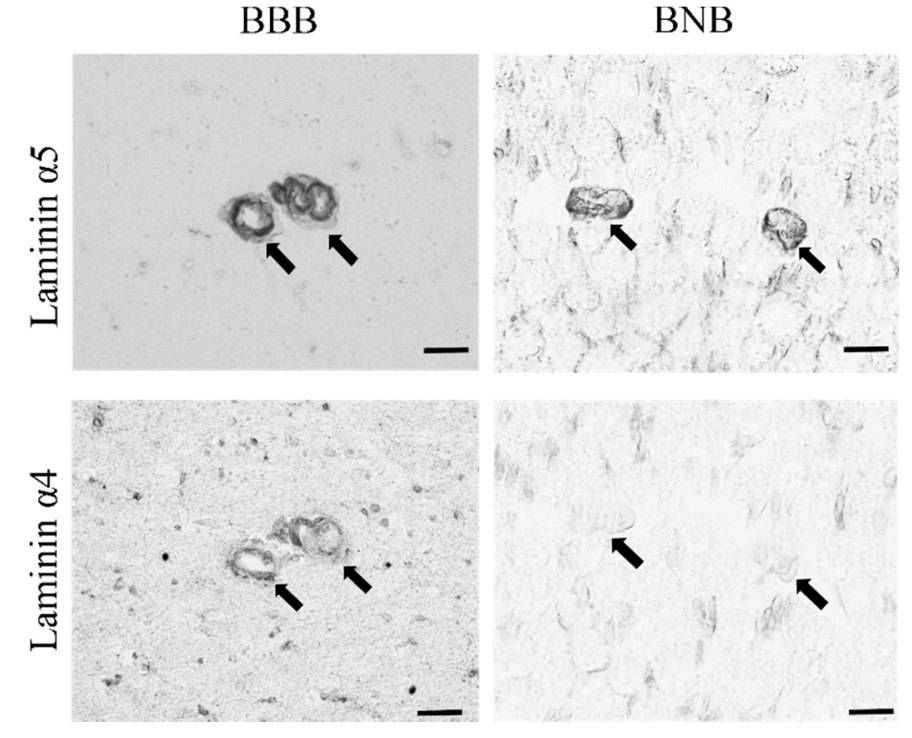

Diabetic neuropathy (BNB)

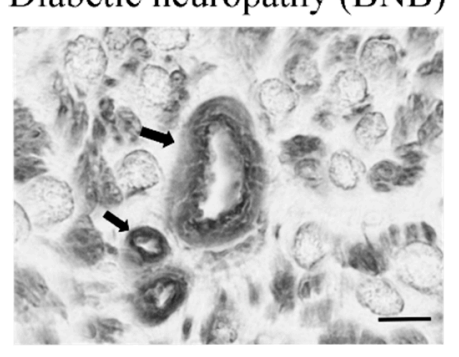

Figure 1. Comparative anatomy of the blood-brain barrier and blood-nerve barrier. (A) Peripheral nerve tissue consists of the blood-nerve barrier and axons of neurons wrapped in Schwann cells. Unlike the blood-brain barrier, which consists of vascular endothelial cells, pericytes, astrocytes, and basal laminae, the blood-nerve barrier consists of vascular endothelial cells, pericytes, and basal laminae. (B) Immunostaining with anti-laminin ( $\alpha 5$ and 4) in the blood-brain barrier (BBB; brain; left panel) and blood-nerve barrier (BNB; median nerve; middle panel) from a postmortem 67-year-old man with amyotrophic lateral sclerosis and from a 67-year-old man with diabetic peripheral neuropathy (DPN; sural nerves; right panel). Laminin $\alpha 5$ immunoreactivity was localized to the microvessels. Only laminin $\alpha 4$ immunoreactivity was lost in the BNB. Bar $10 \mu \mathrm{m}$.

\subsection{Establishment of BNB-Forming Cell Lines and Functions of Pericytes 2.1.1. Establishment of BNB-Forming Cell Lines}

To clarify the mechanism underlying BNB disruption in DPN, we established temperature-sensitive immortalized cell lines of vascular endothelial cells and pericytes originating from human BNB (Figure 2A,B). We extracted endoneurial vessels from human 
sciatic nerves obtained at autopsy. Endothelial cells and pericytes were then isolated and cultured. These cells were immortalized by introducing the temperature-sensitive SV40 large T-antigen gene using the same retrovirus vector. The vascular endothelial cells were characterized by their spindle-fiber-shaped morphology, expression of von Willebrand factor, expression of tight junction-related molecules, and high electrical resistance, which were consistent with the characteristics of BNB-forming endothelial cells [7,15]. Pericytes were characterized by their cobblestone-shaped morphology and identified by their ruffled borders and the expressions of $\alpha$-smooth muscle actin ( $\alpha$-SMA), PDGF- $\beta$ receptor (PDGF $\beta R$ ), osteopontin, and desmin [16,17]. After our report, Vosef et al. established BNB-forming vascular endothelial cell lines derived from human sciatic nerves [18,19]. These cell lines were immortalized by introducing the SV40 large T-antigen gene. However, the continuous passage of immortalized cell lines by serial introduction of the SV40 large T-antigen gene may alter the morphology of cells, leading to a loss of their biochemical function [20]. The human cell lines derived from endothelial cells forming the BNB (hEC-BNB) and the pericytes forming the BNB (hPCT-BNB), established in the present study, were conditionally immortalized by introducing the temperature-sensitive SV40 large T-antigen gene (Figure 2C). The SV40 large T-antigen gene was inactivated by culturing at $37^{\circ} \mathrm{C}$, leading to a loss of immortalization. The cell lines were, therefore, considered to have physiological and biochemical functions similar to in vivo conditions [7,17].
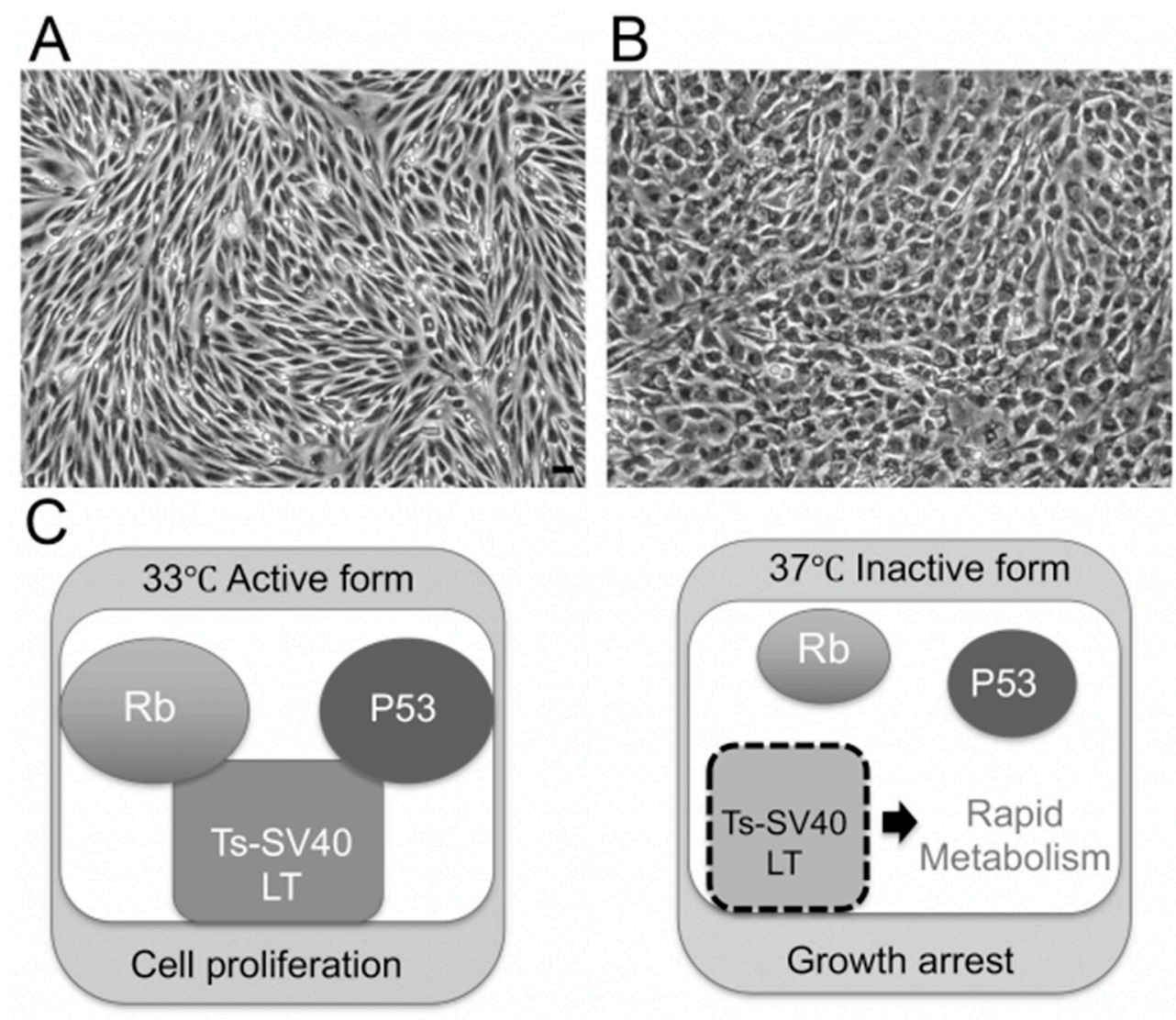

Figure 2. Establishing the BNB cell lines that maintain BNB properties. (A) Morphology of hEC-BNB (human endothelial cells in BNB) is spindle-shaped. (B) Morphology of hPCT-BNB (human pericytes in BNB) is cobblestone-shaped. (C) Temperature-sensitive SV40 large T antigen. At $33^{\circ} \mathrm{C}$, TS-SV40LT binds and inhibits p53 and $\mathrm{Rb}$, which are strong tumor suppressors, leading to continuous cell proliferation. At $37^{\circ} \mathrm{C}$, TS-SV40-LT is inactivated, and the cells exhibit growth arrest and differentiate into endothelial cells. Scale bar represents $10 \mu \mathrm{m}$. 


\subsubsection{Function of Pericytes in the BNB}

In the BBB, endothelial cells function as an important barrier; however, they alone cannot maintain the physiological barrier, and continuous "crosstalk" between cellular and non-cellular components surrounding these cells is considered essential for maintaining the barrier. Astrocytes have been recognized as important BBB regulators [21], and in recent years, pericytes have also been described as important BBB regulators [22,23]. In 2010, Armulik et al. reported transcytosis in BBB-forming endothelial cells, leading to increased permeability of the BBB in pericyte-deficient mice [16]. Since cells such as astrocytes are not present in the $\mathrm{BNB}$, it is assumed that pericytes play an important role in regulating the BNB. Using BNB-forming cell lines, we previously demonstrated the following results: (1) pericyte culture supernatant increased the electrical resistance (trans-endothelial electrical resistance) and decreased the permeability of 14C-labeled inulin in endothelial cell lines originating from the BNB; (2) pericyte culture supernatant increased the expression of tight junction-related proteins (claudin-5, occludin) in endothelial cell lines originating from the BNB; (3) pericytes secrete physiologically active substances (angiopoietin-1 (Ang-1), vascular endothelial growth factor (VEGF), basic fibroblast growth factor (bFGF), and a neurotropic factor (glial cell line-derived neurotrophic factor, GDNF)); (4) Ang-1 and VEGF secreted by pericytes decreased the expression of claudin-5, leading to a tendency to decrease BNB function; and (5) bFGF and GDNF, in contrast, increased the expression of claudin-5 [17,24]. These findings demonstrate that pericytes play an important role as BNB regulators.

\subsubsection{Construction of a New In Vitro BNB Model}

BNB plays crucial roles in the maintenance of peripheral nervous system homeostasis and in the pathogenesis of DPN. The BNB components (pericytes and basement membrane such as laminin $\alpha 5, \beta 1, \gamma 1$ ) have directly contact with the endothelial cells and participate the regulation of each barrier function. However, the mechanism of this regulation still remains unknown because of the non-existence of the in vitro human BNB model in which these components can directly come in contact with endothelial cells (Figure 3A,B). Recently, we constructed a new in vitro human BNB model that incorporated a multi-culturing system of these BNB components using the UpCell technology of Nunc (Figure 3C). In this model, firstly, hPCT-BNBs were cultured on the luminal side of the insert-membrane (Figure 3D). Secondly, hEC-BNBs were cultured in an UpCell dish with a coated temperature-responsive polymer, which can achieve sheet-like detachment of confluent cells and extracellular matrix by temperature-shifting to $20^{\circ} \mathrm{C}$. Then, sheet-like detachment of confluent hEC-BNBs were transferred onto the hPCT-BNBs. Confocal 3D analysis with live staining of each cell line showed that the multi-cultured insert constituted the two-layer structures, which consisted of hEC-BNBs and hPCT-BNBs. The layer of hPCT-BNBs was in direct contact with the hEC-BNBs (Figure 3E). 
A

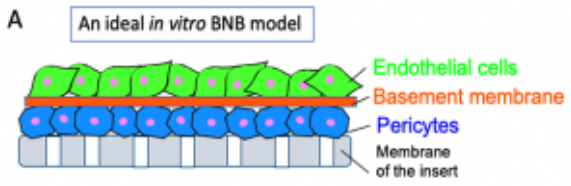

B An actual in vitro BNB model

Seeding of endothelial cells to pericytes' layer $\checkmark$

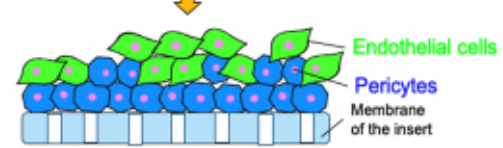

EC disorderly laminate and can't form the BNB c

UpCell ${ }^{\mathrm{TM}}$ dish

The Nunc UpCell ${ }^{\mathrm{TM}}$ technology
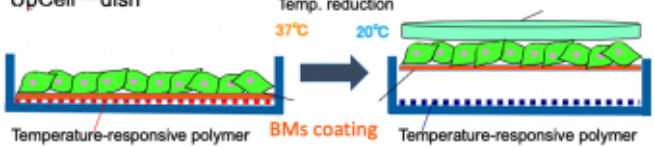
Temperature-respo
(Hydrophobic) Temperature-rosp
(Hydrophilic)

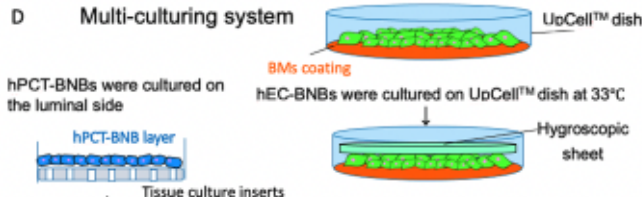
$\downarrow \begin{aligned} & \text { Tissue culture inserts } \\ & \text { with } 3 \text { um pores }\end{aligned}$

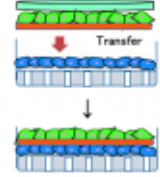

EC-BNBs, BMs and hPCT-BNBs were
multi-cultured at $37^{\circ} \mathrm{C}$

\section{E 3D morphology of multi-culturing cells on the insert}

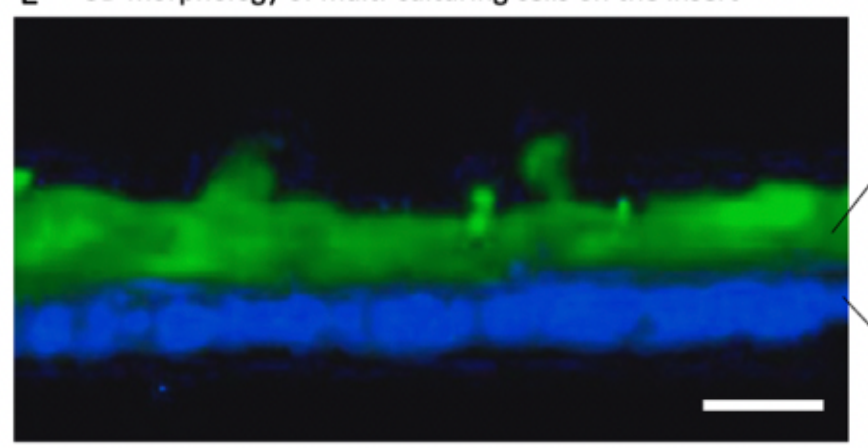

\section{Cell tracker Green:}

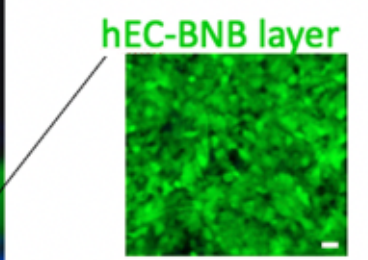

Cell trackerBlue:

hPCT-BNB laver

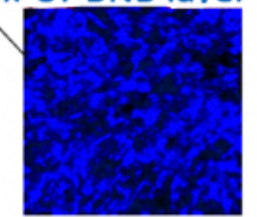

Figure 3. Construction of a new in vitro BNB model. (A) An ideal in vitro human BNB model. The endothelial cells form the monolayer. The BNB components (pericytes and basement membrane) are in direct contact with the monolayer of endothelial cells on the tissue culture insert. (B) An actual in vitro human BNB model. If endothelial cells are forcibly multi-cultured on the layer of pericytes, they disorderly laminate and cannot form the BNB due to the difference in growth speed of each cell line. (C) The Nunc UpCell ${ }^{\mathrm{TM}}$ technology. Temperature-responsive polymer is immobilized on the surface of the $\mathrm{UpCell}^{\mathrm{TM}}$ dish. The polymer-grafted surface shows reversible hydrophobic and hydrophilic properties across the threshold temperature of $20{ }^{\circ} \mathrm{C}$. The cell-sheet is detached from the dish without harmful enzymes (e.g., trypsin or dispase) and attached to the hygroscopic sheet to transfer. (D) Multi-culturing systems. hPCT-BNBs were cultured on the luminal side of the cell culture insert membrane with $3 \mu \mathrm{m}$ pores. After flipping the cultured insert, hPCT-BNBs were cultured on the luminal side. hEC-BNBs were cultured in an UpCell dish. After incubation at 20 ${ }^{\circ} \mathrm{C}$, the sheet of confluent hECs was detached and transferred onto the hPCT-BNBs. (E) Confocal 3D analysis with live staining of hEC-BNBs and hPCT-BNBs. Multi-cultured insert constituted the two-layer structures, which consisted of hEC-BNBs and hPCT-BNBs. The layer of hPCT-BNBs was close to the hEC-BNBs. Bar $=5 \mu \mathrm{m}$.

\section{BNB Disruption}

\subsection{Impaired Barrier Function Owing to Advanced Glycation End Products (AGEs)}

The association between diabetes mellitus and barrier function has been investigated for a long time, and impaired barrier function is considered to be the first stage in the 
development of DPN. In 1987, a study demonstrated that patients with type 1 DPN had increased vascular permeability and high concentrations of high-molecular-weight proteins, such as albumin and immunoglobulin $\mathrm{G}(\mathrm{IgG})$, in the endoneurium. This study revealed, for the first time, that barrier function is impaired by BNB disruption in DPN [25]. In the following year, another study demonstrated that diabetes patients without comorbid peripheral neuropathy also had increased vascular permeability and high concentrations of high-molecular-weight proteins, such as albumin and IgG, in the endoneurium. It was confirmed that chronic hyperglycemia, per se, impairs the barrier function of the BNB [26]. Moreover, it has been reported that when high-molecular-weight proteins transferred to the endoneurium accumulate over a long time, electrolyte regulation is impaired in peripheral nerves, and impaired electrolyte regulation leads to the progression of edema, which causes ischemia of the nerve fascicles [27]. Furthermore, these high-molecular-weight proteins transferred to the endoneurium also include neuropathic humoral factors, which are important risk factors for not only DPN but also various peripheral neuropathies.

Advanced glycation end products (AGEs) are neurotoxic humoral factors released into the endoneurium. AGEs are rapidly generated by a continuous hyperglycemic state and are greatly involved in the pathogenesis of diabetic microvascular complications, including nephropathy, retinopathy, and dementia [28,29]. In diabetic neuropathy, AGEs accumulate in Schwan cells and axons in peripheral nerves and in BNB-forming cells (vascular endothelial cells, pericytes, and basement membrane) [30]. AGEs are also involved in the progression of diabetic neuropathy. In diabetic nephropathy, glomerular basement membrane thickening occurs. The mechanism involves the release of TGF- $\beta$ from AGEstimulated mesangial cells, which increases the production of type IV collagen that forms the basement membrane [31]. In diabetic retinopathy, AGEs accumulate in retinal vessels, which increase VEGF expression, leading to the disruption of the blood-retinal barrier and an increase in the permeability of retinal microvascular vessels [32].

Our study using immortalized cell lines of endothelial cells and pericytes originating from human BNB showed that AGEs decreased the amount of claudin- 5 by increasing the autocrine secretion of VEGF from endothelial cells forming the BNB, leading to disrupted barrier function, thereby suggesting that AGEs are closely involved in the pathogenesis of BNB disruption (Figure 4).

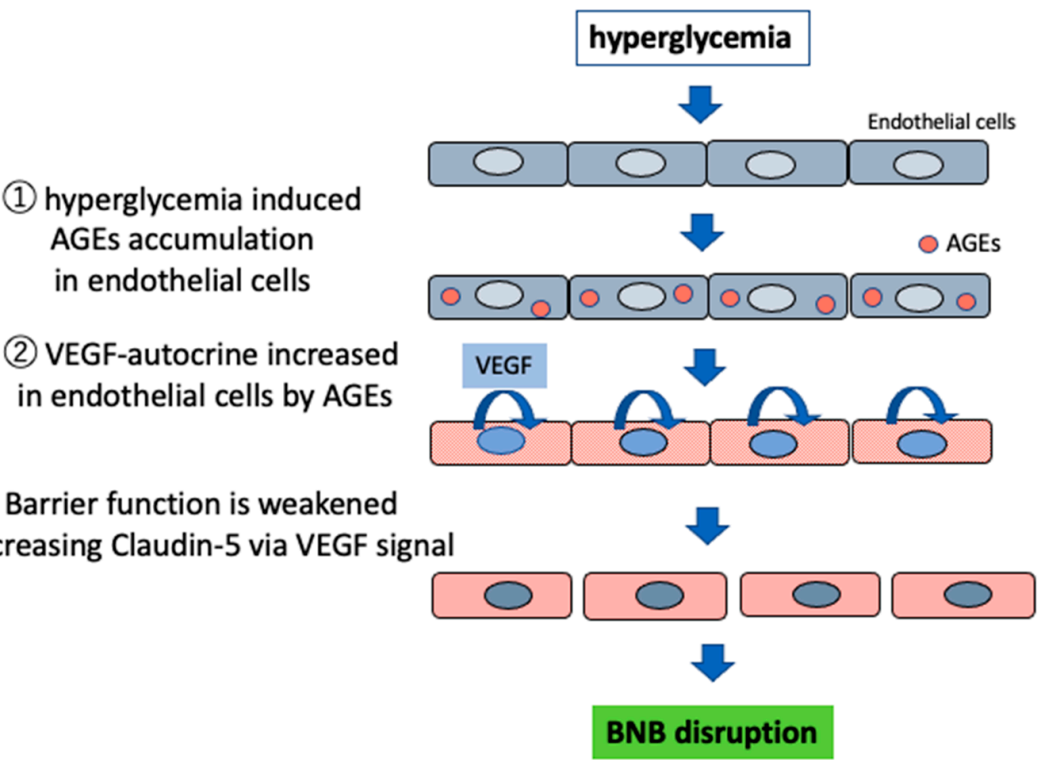

Figure 4. BNB disruption in hyperglycemia by advanced glycation end products (AGEs). Hyperglycemia induced AGE accumulation in endothelial cells. Then, accumulated AGEs increased autocrine VEGF in endothelial cells. Finally, VEGF signal decreased claudin-5 and weakened barrier function. 


\subsection{Microvascular Basement Membrane Thickening in DPN}

In DPN, as described above, hyperglycemia directly causes cellular dysfunction in peripheral nerve tissues, such as enhancement of the polyol metabolic pathway. Furthermore, BNB disruption is induced, resulting in various pathological conditions including impaired barrier function, induction of local inflammation, poor circulation, hypoxia, and damage to Schwann cells and neurons.

Since the late 1970s, studies have reported morphological changes of BNB that suggest its disruption in DPN. These changes include hyperplasia of endothelial cells, dissociation of the tight junction of endothelial cells, microvascular occlusion, fenestrated microvascular endothelial cells, endoneurial microvascular basement membrane thickening, and degeneration of microvessel-forming endothelial cells and pericytes [33-35]. Among these, microvascular basement membrane thickening (Figure 5) is a common finding in diabetic neuropathy; however, its molecular mechanisms have not been elucidated.

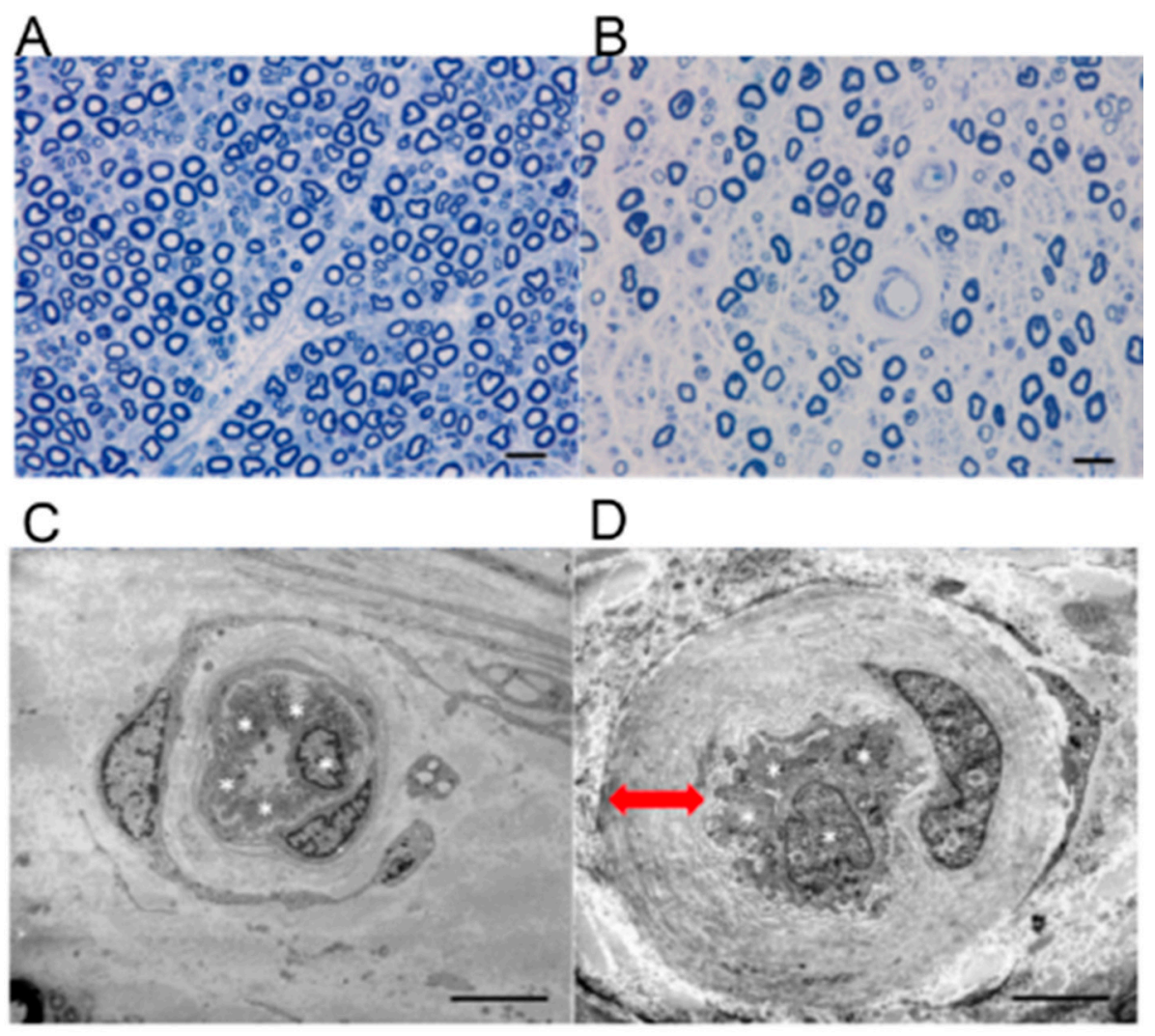

Figure 5. Pathological findings of diabetic peripheral neuropathy. Upper row: Images of sural nerve biopsy specimens from a patient with diabetic peripheral neuropathy and a healthy individual (Epon-embedded specimens; toluidine blue staining); (A) healthy case, 55 year old male; (B) diabetic peripheral neuropathy case, 60 year old male. Compared with the specimen from the healthy individual, the specimen from patient with diabetic peripheral neuropathy shows more extensive loss of myelinated nerve fibers in the endoneurium. Generally, residual myelinated nerve fibers are homogeneously distributed in the same nerve fascicle. Bar $=50 \mu \mathrm{m}$. Lower row: Electron micrographs of small blood vessels in the endoneurium (left, healthy case; right, diabetic peripheral neuropathy case). (C) The cells in the specimen from a patient with diabetic peripheral neuropathy are swollen such that they almost occlude the lumen of the vessel. (D) Compared with those in the specimen from the diabetic peripheral neuropathy case, in the specimen from a patient with diabetic peripheral neuropathy, the small blood vessel is composed of four vascular endothelial cells $\left.{ }^{*}\right)$. Multiple basal laminae overlap and are thickened $(\leftrightarrow)$. Bar $=2 \mu \mathrm{m}$. 
Using immortalized cell lines of endothelial cells and pericytes originating from human BNB, we showed that pericytes played an important role in producing proteins forming the basement membrane, such as fibronectin and type IV collagen, and tissue inhibitor of metalloprotease-1 (TIMP-1), a molecule inhibiting the degradation of the basement membrane. Thus, pericytes play a crucial role in maintaining the basement membrane in the BNB (Figure 6).

In a hyperglycemic state, AGEs accumulate in pericytes and increase the autocrine secretion of VEGF and TGF- $\beta$, leading to the enhanced production of fibronectin and type IV collagen, suggesting that microvascular basement membrane thickening in diabetic neuropathy is caused by the accumulation of AGEs in pericytes under hyperglycemic conditions via VEGF and TGF- $\beta$ signaling by autocrine secretion by pericytes (Figure 6) $[36,37]$.

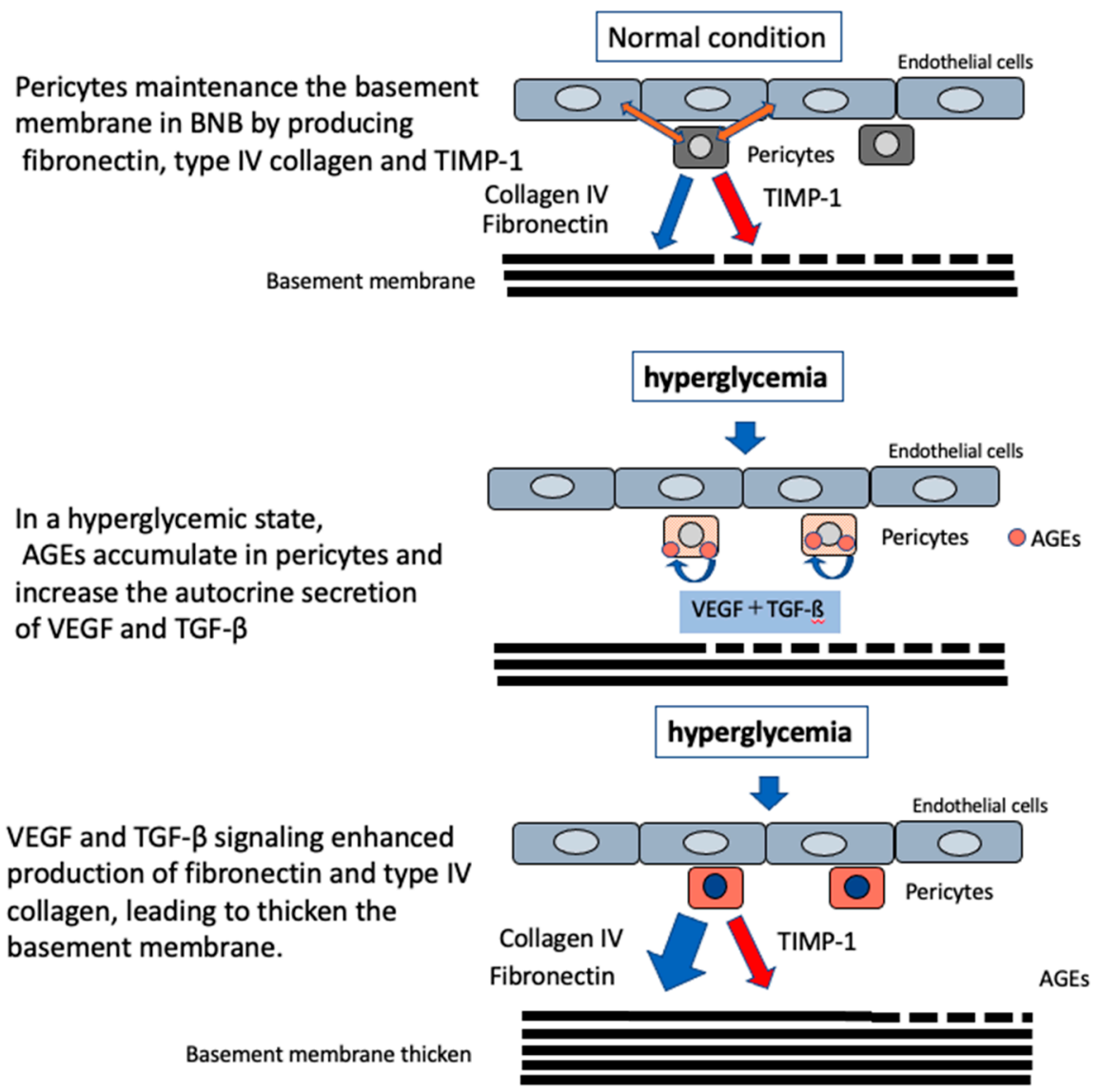

Figure 6. Molecular mechanism modeling of basement membrane thickening in diabetic neuropathy. In normal condition, pericytes maintain the basement membrane in the BNB by producing fibronectin, type IV collagen, and TIMP-1. In hyperglycemia, AGEs accumulate and increase the autocrine secretion of VEGF and TGF- $\beta$ in pericytes. VEGF and TGF- $\beta$ signaling enhanced production of fibronectin and type IV collagen, leading to thickening the basement membrane.

\subsection{Induction of Local Inflammation}

Although DPN is not usually classified as an inflammatory neuropathy, several phenomena are known to occur in diabetic nephropathy and retinopathy. In the microvessels, the endothelium is damaged by oxidative stress, hypoxia, and metabolites such as AGE (bound to the receptors for AGE); consequently, multiple inflammatory signaling cascades are stimulated, and proinflammatory cytokines, such as interleukin $1 \beta$ and tumor necrosis factor- $\alpha$, induce local inflammation [38]. Furthermore, the expression of genes associated with inflammation and immune responses was enhanced in a mouse model of type 2 diabetes mellitus $[39,40]$. It has been hypothesized that DPN induces local inflammation, which in turn contributes to the onset of disordered immune responses and cell infiltra- 
tion [41]. Moreover, elevated expression of genes associated with phagosome formation and excessive stimulation of the toll-like receptor signaling pathway in macrophages in nerve tissues have been reported in patients with DPN [42]. A recent study on sural nerve biopsy in diabetes patients revealed elevated expression of CD40, a surface antigen affecting inflammation and thrombosis in vascular endothelial cells [43]. In 2020, Gonçalves et al. reported that neurotrophin receptor p75, which is expressed by the Schwann cells, was an important key molecule to activate the immune-related pathways and lysosomal stress with in vivo analysis [44]. These findings provide important evidence for the pathology of local inflammatory cell infiltration and microvasculitis in DPN.

\subsection{Disorders Due to Poor Circulation and Hypoxia}

In DPN patients, pathological examination of sural nerve samples shows abnormal vascular findings characterized by swollen vascular endothelial cells in small blood vessels in the endoneurium forming the BNB and a narrowed vascular lumen due to the overlapping and thickening of multiple basal laminae (Figure 5D). Such abnormal blood vessels not only show a decreased expression of tight junction-associated proteins in the blood vessels, but they also show proliferation of the vascular wall due to fibrin, and loss of pericytes surrounding the vascular endothelium. These findings indicate BNB disruption. It is known that the loss of nerve fibers is generally homogeneous across nerve fascicles, which reflects the metabolic disorder due to hyperglycemia (Figure 5B). However, cases have been reported in which the density of residual myelinated nerves was inhomogeneous across nerve fascicles as well as within the same nerve fascicle [45]. These cases indicate that the pathology of DPN includes ischemic neuronal damage due to advanced narrowing of the vascular lumen in addition to metabolic disorder of the peripheral nerves due to hyperglycemia. In fact, decreased oxygen partial pressure in the endoneurium has been previously reported in patients with DPN [46-49]. This explains the ischemic condition of peripheral nerve tissues due to poor circulation. In a mice model, it has been shown that tissue ischemia stimulates macrophages to release vascular endothelial growth factors (VEGFs) [50,51]. As VEGFs increase vascular permeability in the BNB [17], they appear to be important factors for BNB disruption in DPN. Moreover, in the peripheral nerve tissues of patients with DPN, the expression of the transcription factor hypoxia inducible factor-1 (HIF-1), which is induced by an ischemic state, is elevated [43,52]; this induces the expression of various downstream molecules for cellular repair. In particular, the expressions of phosphatase and tensin homolog, which is important for axon repair, and CD40, a surface protein of vascular endothelial cells important for cell infiltration, are elevated [53,54]. In contrast, HIF-1 increases the expression of nicotinamide adenine dinucleotide phosphate oxidase, which induces the production of cytotoxic reactive oxygen species (ROS) in the vascular wall [55,56]. Similar to the pathology reported in the central nervous system [57], the ROS generated in the vascular wall is assumed to cause oxidative damage to the $\mathrm{BNB}$, destruction of the tight junction, and tissue destruction by the activation of matrix metalloproteinases, thereby disrupting the BNB.

\section{The Association between Disruption of Schwann Cells and BNB}

Schwann cells are the most abundant cells in peripheral nerve tissues. The cells surround the axons of neurons to form myelinated and unmyelinated nerves. Owing to close interaction with axons and BNB cells, Schwann cells maintain the homeostasis of peripheral nerve tissues [8]. When metabolic disorder due to hyperglycemia occurs in Schwann cells, peripheral neuropathies, such as demyelination due to the destruction of myelin, disruption of homeostasis in axons, and impaired axonal regeneration, are induced [8]. As described above, a hyperglycemic state enhances the polyol metabolic pathway via increased activity of aldose reductase, even in Schwann cells [58-60], and induces the production of cytotoxic ROS. The generated ROS cause oxidative damage and mitochondrial dysfunction, which develop into cellular disorders of Schwann cells and axons [61]. In a hyperglycemic state, Schwann cells produce the chemokines CXCL9, CXCL10, and CXCL11, which induce the 
local infiltration of CD8+ T-cells [62]. This infiltration leads to the apoptosis of Schwann cells. Consequently, axons are further damaged [62]. Although it is well known that the disruption of Schwan cells by hyperglycemia induced DPN, the interaction between BNB and Schwann cells in DPN is still unknown because of the lack of adequate in vitro human BNB models with Schwann cells and peripheral nerve.

\section{Etiology of Conditions Other than Hyperglycemia}

Needless to say, hyperglycemia is an important factor for DPN. Recent epidemiological studies on DPN in patients with type 1 and type 2 diabetes mellitus have indicated coronary vascular risk factors, such as obesity, dyslipidemia, hypertension, and smoking, might be also involved in the onset of DPN, especially in type 2 diabetes mellitus $[63,64]$. Treatment of hyperglycemia is reported to reduce the incidence of DPN by approximately $60 \%-70 \%$ in patients with type 1 diabetes mellitus $[65,66]$ but by only approximately $5 \%-7 \%$ in patients with type 2 diabetes mellitus $[67,68]$. Furthermore, at least $40 \%$ of patients with type 2 diabetes mellitus develop DPN despite favorable glycemic control [69,70]. As many detailed aspects of molecular mechanisms of these risk factors are unknown, it is possible that these factors exert a bad influence on the BNB.

\section{Conclusions}

As described above, DPN is associated with axonal degeneration caused by metabolic disorder in each type of cell in peripheral nerve tissue due to hyperglycemia and by disruption of the homeostatic mechanism of peripheral nerves due to dysfunction of the BNB and Schwann cells (Figure 7). Previous studies have demonstrated the disruption of the BNB in DPN. Although many pathological findings were found in studies conducted up to around 1980, the molecular mechanism has not been completely investigated owing to limitations in in vitro analysis. As previous epidemiological studies have reported hyperglycemia and coronary vascular risk factors, such as obesity, dyslipidemia, hypertension, and smoking, in DPN, there is a need for research on DPN with a perspective other than hyperglycemia. We succeeded in developing an in vitro BNB model to reflect the anatomical characteristics of the BNB using cell sheet engineering and newly established immortalized cell lines originating from human BNB (Figure 2). We expect that the new in vitro model offers a potential breakthrough for molecular biology studies of DPN in the BNB. 


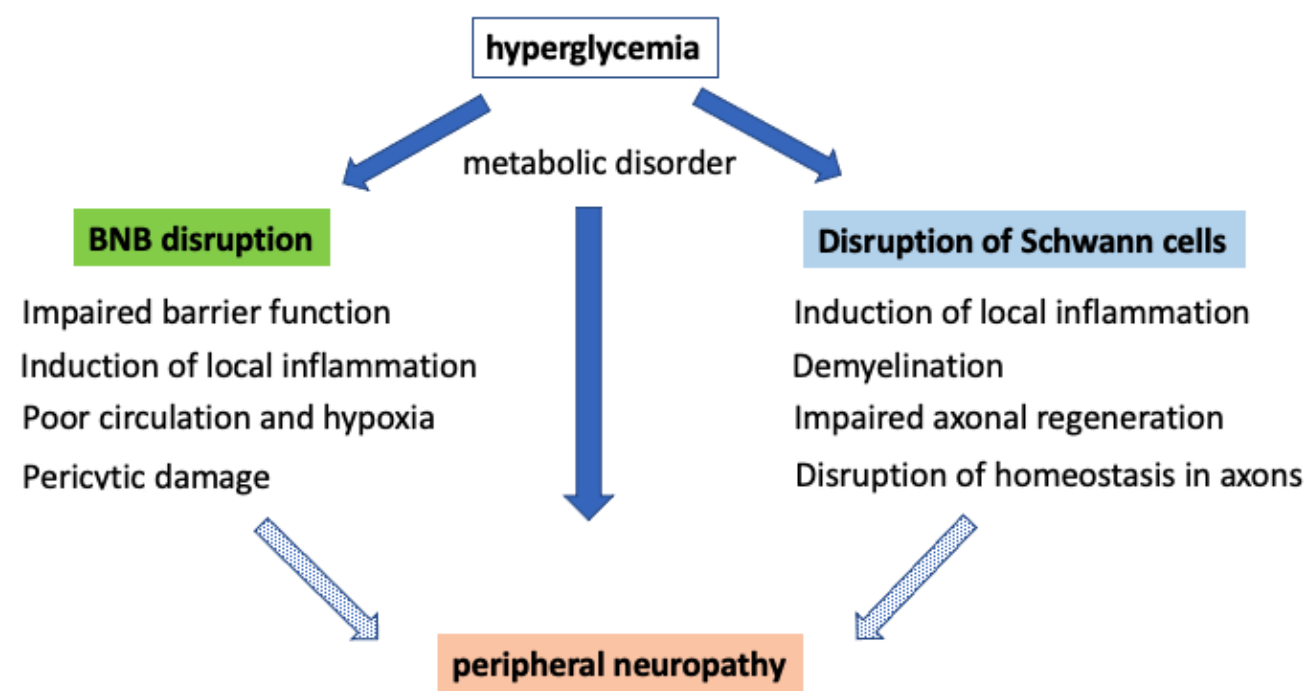

Symmetric polyneuropathy due to metabolic disorder

Focal or multifocal neuropathy due to vascular disorder

Figure 7. The pathological mechanism of neuropathy in diabetes mellitus. Hyperglycemia affects the BNB, Schwann cells, and peripheral nerves. BNB disruption has been confirmed to be associated with various pathological conditions: (1) impaired barrier function by accumulation of cytotoxic high-molecular-weight proteins, (2) induction of vasculitis and the progression of neuropathy due to induced local inflammation, (3) progression of neuropathy due to poor circulation and hypoxia, and (4) disruption of the regulatory mechanism of the BNB due to damaged pericytes. In Schwann cells, metabolic disorder induces the development of peripheral neuropathies such as demyelination, disruption of axonal homeostasis, and impaired axonal regeneration due to the destruction of myelin. Finally, disruption of the BNB and Schwann cells induced clinical types of peripheral neuropathy: (1) symmetric polyneuropathy due to metabolic disorder and (2) focal or multifocal neuropathy due to vascular disorder.

Funding: This study was supported by the Japan Society for the Promotion of Science (JSPS) (JP19K07975).

Acknowledgments: The authors thank Fumitaka Shimizu for showing the in vitro results and Masatoshi Omoto for preparing pathological samples.

Conflicts of Interest: The authors declare no conflict of interest.

$\begin{array}{ll}\text { Abbreviations } \\ \text { AGEs } & \text { Advanced glycation end products } \\ \text { BBB } & \text { Blood-brain barrier } \\ \text { BNB } & \text { Blood-nerve barrier } \\ \text { DPN } & \text { Diabetic peripheral neuropathy } \\ \text { HIF-1 } & \text { Hypoxia inducible factor-1 } \\ \text { IgG } & \text { Immunoglobulin G } \\ \text { ROS } & \text { Reactive oxygen species } \\ \text { VEGFs } & \text { Vascular endothelial growth factors }\end{array}$

\section{References}

1. Saeedi, P.; Petersohn, I.; Salpea, P.; Malanda, B.; Karuranga, S.; Unwin, N.; Colagiuri, S.; Guariguata, L.; Motala, A.A.; Ogurtsova, K.; et al. IDF Diabetes Atlas Committee. Global and regional diabetes prevalence estimates for 2019 and projections for 2030 and 2045: Results from the International Diabetes Federation Diabetes Atlas 9th edition. Diabetes Res. Clin. Pract. 2019, 157, 107843. [CrossRef]

2. Peltier, A.; Goutman, A.S.; Callaghan, B.C. Painful diabetic neuropathy. BMJ 2014, 348, 1799. [CrossRef]

3. Harati, Y. Diabetic neuropathies: unanswered questions. Neurol. Clin. 2007, 25, 303-317. [CrossRef] [PubMed] 
4. Chung, S.; Ho, E.; Lam, K.; Chung, K.S. Contribution of polyol pathway to diabetes-induced oxidative stress. J. Am. Soc. Nephrol. 2003, 14, 233-236. [CrossRef] [PubMed]

5. Giri, B.; Dey, S.; Das, T.; Sarkar, M.; Banerjee, J.; Dash, S.K. Chronic hyperglycemia mediated physiological alteration and metabolic distortion leads to organ dysfunction infection cancer progression and other pathophysiological consequences: An update on glucose toxicity. Biomed. Pharmacother. 2018, 107, 306-328. [CrossRef] [PubMed]

6. Kanda, T. Biology of the blood-nerve barrier and its alteration in immune mediated neuropathies. J. Neurol. Neurosurg. Psychiatry 2013, 84, 208-212. [CrossRef] [PubMed]

7. Abe, M.; Sano, Y.; Maeda, T.; Shimizu, F.; Kashiwamura, Y.; Haruki, H.; Saito, K.; Tasaki, A.; Kawai, M.; Terasaki, T.; et al. Establishment and characterization of humanperipheral nerve microvascular endothelialcell lines: A new in vitro blood-nerve barrier (BNB) model. Cell. Struct. Funct. 2012, 37, 89-100. [CrossRef]

8. Poduslo, J.F.; Curran, G.L.; Berg, C.T. Macromolecular permeability across the blood-nerve and blood-brain barriers. Proc. Natl. Acad. Sci. USA 1994, 91, 5705-5709. [CrossRef]

9. Ubogu, E.E. The molecular and biophysical characterization of the human blood-nerve barrier: Current concepts. J. Vasc. Res. 2013, 50, 289-303. [CrossRef]

10. Cardoso, F.L.; Brites, D.; Brito, M.A. Looking at the blood-brain barrier: molecular anatomy and possible investigation approaches. Brain Res. Rev. 2010, 64, 328-363. [CrossRef]

11. Takeshita, Y.; Omoto, M.; Fujikawa, S.; Kanda, T. Immunohistochemical analysis of laminin components in the blood-nerve barrier and blood-brain barrier. Clin. Exp. Neuroimmunol. 2017, 8, 49-53. [CrossRef]

12. Wu, C.; Ivans, F.; Anderson, P.; Hallmann, R.; Vestweber, D.; Nilsson, P.; Robenek, H.; Tryggvason, K.; Song, J.; Korpos, E.; et al. Endothelial basement membrane laminin alpha5 selectively inhibits T lymphocyte extravasation into the brain. Nat. Med. 2009, 15, 519-527. [CrossRef] [PubMed]

13. Kangwantas, K.; Pinteaux, E.; Penny, J. The extracellular matrix protein laminin-10 promotes blood-brain barrier repair after hypoxia and inflammation in vitro. J. Neuroinflamm. 2016, 13, 25. [CrossRef] [PubMed]

14. Stierli, S.; Imperatore, V.; Lloyd, A.C. Schwann cell plasticity-roles in tissue homeostasis regeneration and disease. Glia 2019, 67, 2203-2215. [CrossRef]

15. Sano, Y.; Shimizu, F.; Nakayama, H.; Abe, M.; Maeda, T.; Ohtsuki, S.; Terasaki, T.; Obinata, M.; Ueda, M.; Takahashi, R.; et al. Endothelial cells constituting blood-nerve barrier have highly specialized characteristics as barrier-forming cells. Cell Struct. Funct. 2007, 32, 139-147. [CrossRef]

16. Shimizu, F.; Sano, Y.; Maeda, T.; Abe, M.; Nakayama, H.; Takahashi, R.; Ueda, M.; Ohtsuki, S.; Terasaki, T.; Obinata, M.; et al. Peripheral nerve pericytes originating fromthe blood-nerve barrier expresses tightjunctional molecules and transporters asbarrier-forming cells. J. Cell Physiol. 2008, 217, 388-399. [CrossRef]

17. Shimizu, F.; Sano, Y.; Abe, M.; Maeda, T.; Ohtsui, S.; Terasaki, T.; Kanda, T. Peripheral nerve pericytes modify the blood-nerve barrier function and tight junctional molecules through the secretion of various soluble factors. J. Cell Physiol. 2011, 226, 255-266. [CrossRef]

18. Yosef, N.; Xia, R.H.; Ubogu, E.E. Developmentand characterization of a novel human invitro blood-nerve barrier model usingprimary endoneurial endothelial cells. J. Neuropathol. Exp. Neurol. 2010, 69, 82-97. [CrossRef]

19. Yosef, N.; Ubogu, E.E. An immortalized humanblood-nerve barrier endothelial cell line for invitro permeability studies. Cell Mol. Neurobiol. 2013, 33, 175-186. [CrossRef]

20. Takeshita, Y.R.; Ansohoff, R.M. Inflammatorycell trafficking across the blood-brainbarrier: Chemokine regulation and in vitromodels. Immunol. Rev. 2012, 248, 228-239. [CrossRef]

21. Abbott, N.J.; Rönnbäck, L.; Hansson, E. Astrocyte-endothelial interactions at theblood-brain barrier. Nat. Rev. Neurosci. 2006, 7, 41-53. [CrossRef] [PubMed]

22. Lindahl, P.; Johansson, B.R.; Levéen, P.; Betsholtz, C. Pericyte loss and microaneurysmformation in PDGF-B-deficient mice. Science 1997, 277, 242-245. [CrossRef] [PubMed]

23. Armulik, A.; Genové, G.; Mäe, M.; Nisancioglu, M.H.; Wallgard, E.; Niaudet, C.; He, L.; Norlin, J.; Lindblom, P.; Strittmatter, K.; et al. Pericytes regulate the bloodbrain barrier. Nature 2010, 468, 557-561. [CrossRef]

24. Shimizu, F.; Sano, Y.; Saito, K.; Abe, M.; Maeda, T.; Haruki, H.; Kanda, T. Pericyte-derived glial cellline-derived neurotrophic factor increase theexpression of claudin-5 in the blood-brainbarrier and the blood-nerve barrier. Neurochem. Res. 2012, 37, 401-409. [CrossRef]

25. Rechthand, E.; Smith, Q.R.; Latker, C.H.; Rapoport, S.I. Altered blood-nerve barrier permeability to small molecules in experimental diabetes mellitus. J. Neuropathol. Exp. Neurol. 1987, 46, 302-314. [CrossRef] [PubMed]

26. Poduslo, J.F.; Curran, G.L.; Dyck, P.J. Increase in albumin IgG and IgM blood-nerve barrier indices in human diabetic neuropathy. Proc. Natl. Acad. Sci. USA 1988, 85, 4879-4883. [CrossRef] [PubMed]

27. Mizisin, A.P.; Weerasuriya, A. Homeostatic regulation of the endoneurial microenvironment during development aging and in response to trauma disease and toxic insult. Acta Neuropathol. 2011, 121, 291-312. [CrossRef]

28. Koschinsky, T.; He, C.J.; Mitsuhashi, T.; Bucala, R.; Liu, C.; Buenting, C.; Heitmann, H.; Vlassara, H. Orally absorbed reactive glycation products (glycotoxins): An environmental risk factorin diabetic nephropathy. Proc. Natl. Acad. Sci. USA 1997, 94, 6474-6479. [CrossRef] 
29. Shimizu, F.; Sano, Y.; Kanda, T. Advancedglycation end-products disrupt the bloodbrain barrier by stimulating the release ofTGF- $\beta$ by pericytes and VEGF and MMP-2by endothelial cells in vitro. Neurobiol. Aging. 2013, 34, 1902-1912. [CrossRef]

30. Wada, R.; Yagihashi, S. Role of advancedglycation end products and their receptors indevelopment of diabetic neuropathy. Ann. N. Y. Acad. Sci. 2005, 1043, 598-604. [CrossRef]

31. Tsilibary, E.C. Microvascular basementmembranes in diabetes mellitus. J. Pathol. 2003, 200, 537-546. [CrossRef] [PubMed]

32. Canning, P.; Glenn, J.V.; Hsu, D.K.; Liu, F.T.; Gardiner, A.T.; Stitt, W.A. Inhibition of advanced glycation and absence ofgalectin-3 prevent blood-retinal barrierdysfunction during short-term diabetes. Exp. Diabetes Res. 2007, 2007, 51837. [CrossRef] [PubMed]

33. Giannini, G.; Giannini, C.; Dyck, P.J. Basement membrane reduplication andpericyte degeneration precede developmentof diabetic polyneuropathy and are associatedwith its severity. Ann. Neurol. 1995, 37, 498-504. [CrossRef] [PubMed]

34. Vinik, A.I.; Mehrabyan, A. Diabeticneuropathies. Med. Clin. N. Am. 2004, 88, 947-999. [CrossRef]

35. Richner, M.; Ferreira, N.; Dudele, A.; Jensen, S.T.; Vaegter, B.C.; Gonçalves, P.N. Functional and Structural Changes of the Blood-Nerve-Barrier in Diabetic Neuropathy. Front Neurosci. 2019, 12, 1038. [CrossRef]

36. Shimizu, F.; Haruki, T.; Kanda, T. Advanced glycation end-products induce basement membrane hypertrophy in endoneurial microvessels and disrupt the blood-nerve barrier by stimulating the release of TGF- $\beta$ and vascular endothelial growth factor (VEGF) by pericytes. Diabetologia 2011, 54, 1517-1526. [CrossRef]

37. Rhee, S.Y.; Kim, S.Y. The Role of Advanced Glycation End Products in Diabetic Vascular Complications. Diabetes Metab. J. 2018, 42, 188-195.

38. Talbot, S.; Chahmi, E.; Dias, J.P.; Couture, R. Key role for spinal dorsal horn microglial kinin B1 receptor in early diabetic pain neuropathy. J. Neuroinflamm. 2010, 7, 36. [CrossRef]

39. O’Brien, P.D.; Hur, J.; Hayes, M.J.; Backus, C.; Sakowski, A.S.; Feldman, L.E. BTBR ob/ob mice as a novel diabetic neuropathy model: Neurological characterization and gene expression analyses. Neurobiol. Dis. 2015, 73, 348-355. [CrossRef]

40. Hinder, L.M.; Murdock, B.J.; Park, M.; Bender, E.D.; O’Brien, P.D.; Rumora, E.A.; Hur, J.; Feldman, L.E. Transcriptional networks of progressive diabetic peripheral neuropathy in the $\mathrm{db} / \mathrm{db}$ mouse model of type 2 diabetes: An inflammatory story. Exp. Neurol. 2018, 305, 33-43. [CrossRef]

41. Nguyen, D.V.; Shaw, C.L.; Grant, B.M. Inflammation in the pathogenesis of microvascular complications in diabetes. Front. Endocrinol. 2012, 3, 170. [CrossRef] [PubMed]

42. Zhu, T.; Meng, Q.; Ji, J.; Lou, X.; Zhang, L. Toll-like receptor 4 and tumor necrosis factor-alpha as diagnostic biomarkers for diabetic peripheral neuropathy. Neurosci. Lett. 2015, 585, 28-32. [CrossRef] [PubMed]

43. Kan, H.; Hsieh, J.-H.; Chien, H.-F.; Lin, Y.-H.; Yeh, T.-Y.; Chao, C.-C.; Hsieh, S.-T. CD40-mediated HIF-1 $\alpha$ expression underlying microangiopathy in diabetic nerve pathology. Dis. Model. Mech. 2018, 11, dmm033647. [CrossRef] [PubMed]

44. Gonçalves, P.N.; Jager, E.S.; Richner, M.; Murray, S.S.; Mohseni, S.; Jensen, S.T.; Vaegter, B.C. Schwann cell p75 neurotrophin receptor modulates small fiber degeneration in diabetic neuropathy. Glia 2020, 68, 2725-2743. [CrossRef] [PubMed]

45. Dyck, P.J.; Karnes, L.J.; Okazaki, H.; Lais, A.; Engelstad, J. The spatial distribution of fiber loss in diabetic polyneuropathy suggests ischemia. Ann. Neurol. 1986, 19, 440-449.

46. Tuck, R.R.; Schmelzer, J.D.; Low, A.P. Endoneurial blood flow and oxygen tension in the sciatic nerves of rats with experimental diabetic neuropathy. Brain 1984, 107, 935-950. [CrossRef] [PubMed]

47. Newrick, P.G.; Wilson, J.A.; Jakubowski, J.; Boulton, J.A.; Ward, D.J. Sural nerve oxygen tension in diabetes. Br. Med. J. 1986, 293, 1053-1054. [CrossRef]

48. Cameron, N.E.; Cotter, A.M.; Dines, C.K.; Maxfield, K.E.; Carey, F.; Mirrless, J.D. Aldose reductase inhibition nerve perfusion oxygenation and function in streptozotocin-diabetic rats: Dose-response considerations and independence from a myo-inositol mechanism. Diabetologia 1994, 37, 651-663. [CrossRef]

49. Ibrahim, S.; Harris, D.N.; Radatz, M.; Seimi, F.; Rajbhandari, S.; Brady, L.; Jakubowski, J.; Ward, D.J. A new minimally invasive technique to show nerve ischaemia in diabetic neuropathy. Diabetologia 1999, 42, 737-742. [CrossRef]

50. Lim, T.; Shi, X.; Johnson, M.J.; Rone, B.M.; Antel, P.J.; David, S.; Zhang, J. Peripheral nerve injury induces persistent vascular dysfunction and endoneurial hypoxia contributing to the genesis of neuropathic pain. J. Neurosci. 2015, 35, 3346-3359. [CrossRef]

51. Xiong, M.; Elson, G.; Legarda, D.; Leibovich, J.S. Production of vascular endothelial growth factor by murine macrophages: Regulation by hypoxia lactate and the inducible nitric oxide synthase pathway. Am. J. Pathol. 1998, 153, 587-598. [CrossRef]

52. Lokmic, Z.; Musyoka, J.; Hewitson, D.T.; Darby, A.I. Hypoxia and hypoxia signaling in tissue repair and fibrosis. Int. Rev. Cell Mol. Biol. 2012, 296, 139-185. [PubMed]

53. Park, K.K.; Liu, K.; Hu, Y.; Kanter, L.J.; He, Z. PTEN/mTOR and axon regeneration. Exp. Neurol. 2010, 223, 45-50. [CrossRef] [PubMed]

54. Singh, B.; Singh, V.; Krishnan, A.; Koshy, K.; Martinez, A.J.; Cheng, C.; Almquist, C.; Zochodne, W.D. Regeneration of diabetic axons is enhanced by selective knockdown of the PTEN gene. Brain 2014, 137, 1051-1067. [CrossRef] [PubMed]

55. Yuan, G.; Khan, A.S.; Luo, W.; Nanduri, J.; Semenza, L.G.; Prabhakar, R.N. Hypoxia-inducible factor 1 mediates increased expression of NADPH oxidase-2 in response to intermittent hypoxia. J. Cell Physiol. 2011, 226, 2925-2933. [CrossRef]

56. Gonçalves, N.P.; Vægter, B.C.; Andersen, H.; Østergaard, L.; Calcutt, A.N.; Jensen, S.T. Schwann cell interactions with axons and microvessels in diabetic neuropathy. Nat. Rev. Neurol. 2017, 13, 135-147. [CrossRef]

57. Pun, P.B.; Lu, J.; Moochhala, S. Involvement of ROS in BBB dysfunction. Free Radic. Res. 2009, 43, 348-364. [CrossRef] 
58. Ng, T.F.; Lee, K.F.; Song, T.Z.; Calcutt, A.N.; Lee, Y.A.; Chung, S.; Chung, S.K. Effects of sorbitol dehydrogenase deficiency on nerve conduction in experimental diabetic mice. Diabetes 1998, 47, 961-966. [CrossRef]

59. Song, Z.; Fu, W.T.D.; Chan, Y.-S.; Leung, S.; Chung, M.S.S.; Chung, K.S. Transgenic mice overexpressing aldose reductase in Schwann cells show more severe nerve conduction velocity deficit and oxidative stress under hyperglycemic stress. Mol. Cell. Neurosci. 2003, 23, 638-647. [CrossRef]

60. Uehara, K.; Yamagishi, S.; Otsuki, S.; Chin, S.; Yagihashi, S. Effects of polyol pathway hyperactivity on protein kinase C activity nociceptive peptide expression and neuronal structure in dorsal root ganglia in diabetic mice. Diabetes 2004, 53, 3239-3247. [CrossRef]

61. Viader, A.; Sasaki, Y.; Kim, S.; Strickland, A.; Workman, S.C.; Yang, K.; Gross, W.R.; Milbrandt, J. Aberrant Schwann cell lipid metabolism linked to mitochondrial deficits leads to axon degeneration and neuropathy. Neuron 2013, 77, 886-898. [CrossRef] [PubMed]

62. Tang, W.; Lv, Q.; Chen, X.; Zou, J.; Liu, Z.; Shi, Y. CD8(+) T cell-mediated cytotoxicity toward Schwann cells promotes diabetic peripheral neuropathy. Cell. Physiol. Biochem. 2013, 32, 827-837. [CrossRef] [PubMed]

63. Tesfaye, S.; Stevens, K.L.; Stephenson, M.J.; Fuller, H.J.; Plater, M.; Ionescu-Tirgoviste, C.; Nuber, A.; Pozza, G.; Ward, D.J. Prevalence of diabetic peripheral neuropathy and its relation to glycaemic control and potential risk factors: The EURODIAB IDDM Complications Study. Diabetologia 1996, 39, 1377-1384. [CrossRef] [PubMed]

64. Tesfaye, S.; Chaturvedi, N.; Eaton, M.E.S.; Ward, D.J.; Manes, C.; Ionescu-Tirgoviste, C.; Witte, R.D.; Fuller, H.J. EURODIAB Prospective Complications Study Group. Vascular risk factors and diabetic neuropathy. N. Engl. J. Med. 2005, 352, 341-350. [CrossRef] [PubMed]

65. The Diabetes Control and Complications Trial Research Group. N. Engl. J. Med. 1993, 329, 977-986.

66. Linn, T.; Ortac, K.; Laube, H.; Federlin, K. Intensive therapy in adult insulin-dependent diabetes mellitus is associated with improved insulin sensitivity and reserve: a randomized controlled prospective study over 5 years in newly diagnosed patients. Metabolism 1996, 45, 1508-1513. [CrossRef]

67. Duckworth, W.; Abraira, C.; Moritz, T.; Reda, D.; Emanuele, N.; Reaven, D.P.; Zieve, J.F.; Marks, J.; Davis, N.S.; Hayward, R.; et al. Glucose control and vascular complications in veterans with type 2 diabetes. N. Engl. J. Med. 2009, 360, 129-139. [CrossRef] [PubMed]

68. Ismail-Beigi, F.; Craven, T.; Banerji, A.M.; Basile, J.; Calles, J.; Cohen, M.R.; Cuddihy, R.; Cushman, C.W.; Genuth, S.; Grimm, H.R.; et al. Effect of intensive treatment of hyperglycaemia on microvascular outcomes in type 2 diabetes: An analysis of the ACCORD randomised trial. Lancet 2010, 376, 419-430. [CrossRef]

69. Callaghan, B.C.; Cheng, T.H.; Stables, L.C.; Smith, L.A.; Feldman, L.E. Diabetic neuropathy: Clinical manifestations and current treatments. Lancet Neurol. 2012, 11, 521-534. [CrossRef]

70. Ang, L.; Jaiswal, M.; Martin, C.; Pop-Busui, R. Glucose control and diabetic neuropathy: Lessons from recent large clinical trials. Curr. Diabetes Rep. 2014, 14, 528. [CrossRef] 